地すべり 第 31 巻 第 1 号

Journal of Japan Landslide Society 31-1(1994)

\title{
移動観測による地すべり斜面の管理基準値 \\ A Proposal of the Warning Criterion for the Landslide Crisis \\ Depended on the Observation Data of Sliding Distance
}

\author{
丸山清 輝* 小嶋 伸 一* \\ Kiyoteru MARUYAMA Shinichi KozIMA
}

\begin{abstract}
In this paper, it was studied on improving of warning criterion for landslide. For improving of warning criterion, it was investigated on some actual criteria and landslide movement data. As the result, every landslides have different time to fracture, if they move at same velocity. Therefore, an adequate criterion has to decide for each landslide. It was proposed a forecasting method of time to fracture using some factors of landslide configuration.
\end{abstract}

キーワード：移動観測*，管理基準値*，地すべり滑落余裕時間予測法*

\section{1.まえがき}

わが国では，毎年のように豪雨，融雪，道路建設等の 土工等により地すべり災害が発生している。これらの地 すべり災害では，地すべり動態観測が実施され，この観 測結果をもとに, 応急対策, 緊急対策, 避難等の判断が 成されている。その際には, どの種の計測器で, どの程 度の変動值を記録したならば，どのように対処すべきか の判断基準（管理基準値）が重要である。

現在，管理基準値としては，各現場毎に設けた基準值， 学会等で発表された基準值等がある。しかし, 経験によ るものが多く，現状では，地すべり災害毎に専門家の判 断に頼らざるを得ない場合が多い。

そこで，管理基準值の精度向上を図ることを目的とし て，建設省の各地方建設局，北海道開発局，都道府県， 道路公団等における管理基準值の設定状況の調查及び, 移動観測デー夕をもとにした地すべり 斜面の管理基準值 の検討を実施した。本報文では，その結果を示す。

\section{2. 管理基準值の設定状況}

管理基準の設定に用いられる計測器としては，伸縮計， 地盤傾斜計，孔内傾斜計，雨量計等が挙げられる。この 中で, 伸縮計は, 道路公団の調査によれば, 圧倒的に多 く用いられていると報告されている1。これは, 他の計測 器に比べて, 計測が簡単であることや地すべりの移動量 を直接知ることができるためと考えられる。したがって， 今回の調查では，伸縮計による管理基準値の設定状況を 中心に調查した。調查は, 建設省の各地方建設局, 北海

* 建設省土木研究所
道開発局，都道府県，道路公団等が管理する現場につい て実施した。その結果，地すべり防止区域に関連した地 すべり地（以下「地すべり地関連」とする）が 15ヶ所, 道路に関連した地すべり地（以下「道路関連」とする） が9ヶ所，ダムに関連した地すべり地（以下「ダム関連」 とする）が7ヶ所の各データが得られた。

表ー1には，地すべり地関連の移動量をもとにした管 理基準値を示した。管理基準值の設定は，注意，警戒， 避難，立入禁止の全ての段階について設定されているも のと，注意，警戒，避難及び立入禁止までのもの，警戒

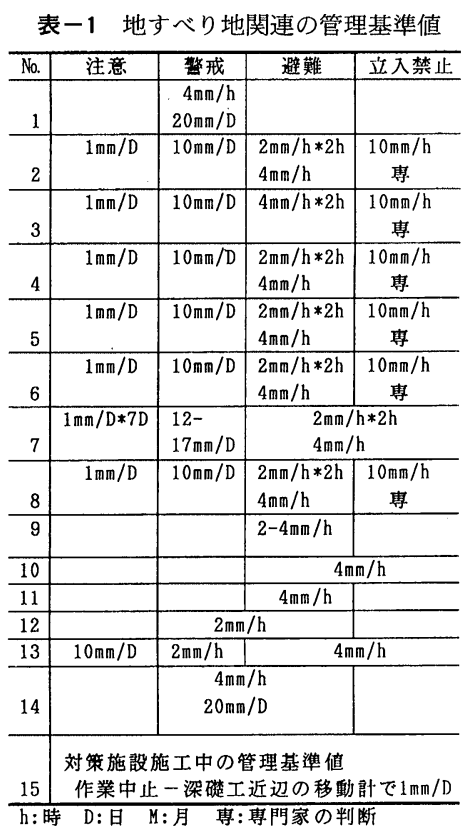


または避難のみのもの等と部分的に設定されているもの とがある。注意段階における管理基準値は，1 mm/日が 6 件と一番多く, $1 \mathrm{~mm} /$ 日が 7 日間継続した時が 1 件, 10 $\mathrm{mm} /$ 日が 1 件となっており，日移動量により設定されて いる。警戒段階における管理基準値は, $10 \mathrm{~mm} /$ 日が 6 件 と一番多く, $4 \mathrm{~mm} /$ 時または $20 \mathrm{~mm} /$ 日が 2 件 ( 1 件は警 戒及び避難)，12-17 mm/日が 1 件， $2 \mathrm{~mm} /$ 時が 2 件 (1 件は警戒及び避難）となっており，注意段階と同様に日 移動量により設定されている場合が多い。また，避難段 階における管理基準値は, $2 \mathrm{~mm} /$ 時が 2 時間継続した時 または $4 \mathrm{~mm} /$ 時が 6 件と一番多く, $4 \mathrm{~mm} /$ 時が 3 件（2 件は避難及び立入禁止)，2-4 mm/時が 1 件， $4 \mathrm{~mm} /$ 時 が 2 時間継続した時が 1 件となっている。立入禁止段階 では, 専門家の判断による $10 \mathrm{~mm} /$ 時が設定値となって いる。また，避難及び立入禁止の段階では，注意及び警 戒段階と異なり，時間移動量の值が設定されている。こ の他，対策工事中の管理基準值（作業中止）として，深 礎の近辺に位置する移動計による $1 \mathrm{~mm} /$ 日が設定值と されている。

表一2には，道路関連の移動量をもとにした管理基準 值を示した。点検段階では $0.02 \mathrm{~mm} /$ 日または $0.5 \mathrm{~mm} /$ 月，応急対策・調査の段階では $0.1 \mathrm{~mm} /$ 日または $2 \mathrm{~mm} /$ 月と $0.1 \mathrm{~mm} /$ 日，対策の実施段階では $1 \mathrm{~mm} /$ 日または $10 \mathrm{~mm} /$ 月と $1.0 \mathrm{~mm} /$ 日が各々設定値とされている。ま た，通行止めの管理基準值としては， $2 \mathrm{~mm} /$ 時の 3 件と $2 \mathrm{~mm} /$ 時または $10 \mathrm{~mm} /$ 日の 1 件が各々設定值とされて

表-2 道路関連の管理基準値

\begin{tabular}{|c|c|c|c|c|}
\hline No. & 点檢 & 応急対策・眮査 & 対策实施 & 通行止め \\
\hline & $0.02 \mathrm{~mm} / \mathrm{D}$ & $0.1 \mathrm{~mm} / \mathrm{D}$ & $1 \mathrm{~mm} / \mathrm{D}$ & \\
\hline 1 & $0.5 \mathrm{~mm} / \mathrm{M}$ & $2 \pi / M$ & $10 \mathrm{~mm} / \mathrm{M}$ & \\
\hline 2 & $0.02 \mathrm{~mm} / \mathrm{D}$ & $0.1 \mathrm{~mm} / \mathrm{D}$ & $1 \mathrm{~mm} / \mathrm{D}$ & \\
\hline 3 & & & & $2 \mathrm{~mm} / \mathrm{h}$ \\
\hline 4 & & & & $2 \mathrm{~mm} / \mathrm{h}$ \\
\hline 5 & & & & $2 \mathrm{~mm} / \mathrm{h}$ \\
\hline 6 & & & & $\begin{array}{r}2 \mathrm{~mm} / \mathrm{h} \\
10 \mathrm{~mm} / \mathrm{D}\end{array}$ \\
\hline 7 & \multicolumn{4}{|c|}{ 対策施即施工中の管理基準値一作業中止 $10 \mathrm{~mm} / \mathrm{D}$} \\
\hline 8 & 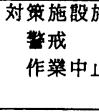 & $\begin{array}{l}\text { 工中の管理基迕1 } \\
\text { 4mm/D } \\
\text { 地すべり末端 } \\
\text { その他での工 }\end{array}$ & び地中での & 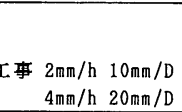 \\
\hline 9 & 対策施殷放 & 工中の管理基準 & - 作業中止 & $10 \mathrm{~mm} / \mathrm{D}$ \\
\hline
\end{tabular}

表-3 ダム関連の管理基準値

\begin{tabular}{|c|c|c|}
\hline No. & 観測强化及び巡視 & 試験满水中止 \\
\hline 1 & 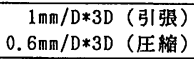 & $\begin{array}{c}3 \mathrm{~mm} / 3 \mathrm{D} \\
\text { 専門家と協䜵 }\end{array}$ \\
\hline 2 & $0.4 \mathrm{~mm} / \mathrm{D}$ & \\
\hline 3 & $0.4 \mathrm{~mm} / \mathrm{D} * 3 \mathrm{D}$ & 専門家と協議 \\
\hline 4 & $0.4 \mathrm{~mm} / \mathrm{D} * 3 \mathrm{D}$ & 専門家と協議 \\
\hline 5 & $4 \mathrm{~mm} / \mathrm{h}$ & \\
\hline 6 & & $\begin{array}{c}1 \mathrm{~mm} / \mathrm{D} \\
\text { 専門家と協議 }\end{array}$ \\
\hline 7 & $0.4 \mathrm{~mm} / \mathrm{D} * 3 \mathrm{D}$ & $\begin{array}{c}1 \mathrm{~mm} / \mathrm{D} \\
\text { 曹門家と協議 }\end{array}$ \\
\hline
\end{tabular}

いる。この他，地すべり対策工事中の管理基準値として， 警戒段階で $4 \mathrm{~mm} /$ 日, 作業中止段階で $10 \mathrm{~mm} /$ 日と, 作 業場所により, 地すべり斜面末端及び地中での作業の場 合は $2 \mathrm{~mm} /$ 時または $10 \mathrm{~mm} /$ 日，それ以外では， $4 \mathrm{~mm} /$ 時または $20 \mathrm{~mm} /$ 日が各々設定值とされている。

表ー3には, ダム関連の移動量をもとにした管理基準 值を示した。観測強化及び巡視段階では, $0.4 \mathrm{~mm} /$ 日が 3 日間継続した時が 3 件, $0.4 \mathrm{~mm} /$ 日と $1 \mathrm{~mm} /$ 日 (引張) が 3 日間継続した時または $0.6 \mathrm{~mm} /$ 日（圧縮）が 3 日間 継続した時が各 1 件となっている。また, 試験湛水中止 については, 3 日間の累積が $3 \mathrm{~mm}$ と $1 \mathrm{~mm} /$ 日が管理基 準值となっているが，全て専門家と協議することになっ ている。

以上のことをまとめると，次のようになる。

地すべり地関連については，注意及び警戒段階では日 移動量, 避難及び立入禁止段階では時間移動量をもとに 管理基準值が設定されている。また, 管理基準值は, 注 意段階が $1 \mathrm{~mm} /$ 日, 警戒段階が $10 \mathrm{~mm} /$ 日, 避難段階が $2 \mathrm{~mm} /$ 時が 2 時間継続した時または $4 \mathrm{~mm} /$ 時, 立入禁止 段階が $10 \mathrm{~mm} /$ 時が多く各々設定値とされている。

道路関連については, 点検, 応急対策・調査, 対策の 実施段階では日移動量が, 通行止めについては時間移動 量をもとに各段階の管理基準值が設定されている。また， 管理基準值は, 通行止めでは $2 \mathrm{~mm} /$ 時が多く設定值とさ れている。

ダム関連の管理基準值は, 観測強化及び巡視の各段階 では日移動量で $0.4 \mathrm{~mm} /$ 日が 3 日間継続した時, 試験湛 水の中止では観測データ及び巡視結果をもとに専門家と 協議して決められている。

\section{3 、移動観測データによる管理基準値の検討}

管理基準值設定段階の注意, 警戒, 避難, 立入禁止等 は，地すべりが滑落するまでの余裕時間により分けたも のである。当然のことながら, 注意段階では余裕時間は 長く, 立入禁止段階では短い。また, 注意〜立入禁止段 階における処置内容は, 今回の管理基準值設定状況調查 によれば，表－4 に示すことを実施することとしている。 注意段階では, 観測計器の点検や巡視の開始等を実施し, 地すべりの動きであるかどうかの認定に主眼が置かれた 内容となっている。警戒段階では, 地すべりの動きであ ることが確認されたことから, 常時監視, 対策工の検討

表－4 注意〜立入禁止段階における処置内容

\begin{tabular}{|c|c|c|c|}
\hline 注 & 警 & 避 & 立入禁止 \\
\hline ·観测即器の点検 & - 常時監視 & - 避難開始 & ·立入禁止 \\
\hline - 観測斯器の増設 & - 巡視の増加 & ·交通止め & \\
\hline - 巡視の開始 & - 対策工の検时 & ·工事の中此 & \\
\hline - 情報提供の開始 & 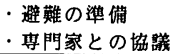 & & \\
\hline
\end{tabular}


等を実施することとしている。また, 避難段階では, 地 すべりの動きが活発化したことから, 避難開始, 工事の 中止等を実施することとしている。この他, 立入禁止段 階では, 地すべりの滑落が間近であることから, 立入禁 止を実施することとしている。

したがって，各管理基準值を設定する際には，実例に 基づいて注意〜立入禁止までの各段階に見合う地すべり 滑落余裕時間が確保された管理基準値を設定する必要が ある。

移動観測データによる地すべりの滑落時間の予測は, 斉藤・上沢の予測法 ${ }^{2)}$ をじめとして, 幾つかの方法 ${ }^{3) \sim 8)}$ が提案され, 滑落間近の状態では精度良く予測された事 例がある9,10)。しかし，地すべり発生初期での滑落時間の 予測は, いづれの方法も精度が良いとは言えない。そこ で，移動観測デー夕を用いて，できるだけ早い時期から 滑落時間の予測ができる方法の開発を目差して検討した。 なお, 移動観測デー夕は, 今回の管理基準値設定状況調 査から得られたものと, 文献に掲載されているものを用 いた。

\section{1 移動観測データ}

移動観測デー夕は, 安居山 (福井県) ${ }^{11}$, 崎方 (長崎 県), 柳谷 (愛媛県) ${ }^{10), 12)}$, JR 山陰本線（奈古～長門大 井, 山口県), JR 東北本線 (浅虫, 青森県) ${ }^{2), 13)}$, 小八重 (宮崎県 $)^{14)}$, 陣出 (山梨県) ${ }^{15)}$ の 7 ヶ所の地すべり地のも のである。

図ー1, 2 には検討に用いた移動観測データを示した。

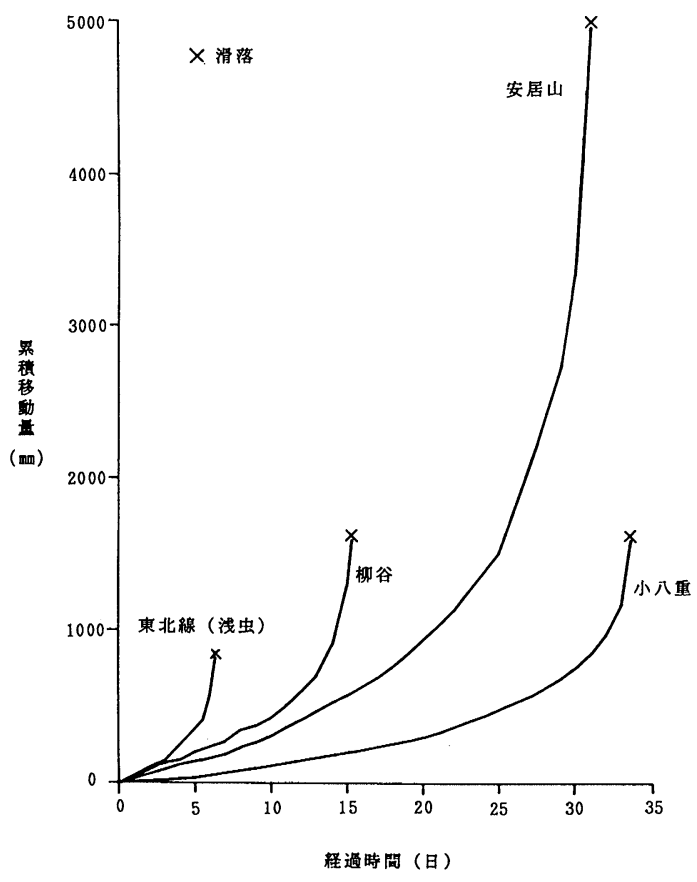

図ー1 移動観測データ(1)

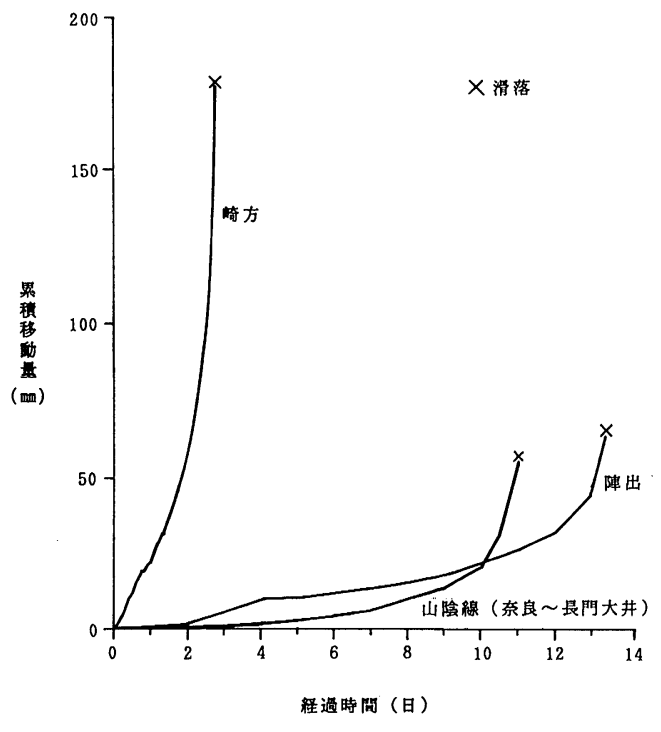

図ー2 移動観測データ(2)

移動観測データは, 管理基準值を移動速度をもとに検討 するために, 応力状態の変化が少なく（降雨等により移 動量の増減のないもの), 地すべり滑落時間が明確であ り，地すべり地の平面図または主測線縦断面図が得られ ているものを用いた。

\section{2 移動速度と地すべり滑落余裕時間との関係}

地すべり地表面移動量をもとにした管理基準値の設定 では, 今回の管理基準値設定状況調査からも分かるよう に, 月移動量, 日移動量, 時間移動量等が用いられてい る。これは, 管理基準值として移動速度を用いた場合, 時々刻々と変化する地すべり斜面の状況を任意の時間毎 に把握することができるためと考えられる。

土がクリープ破壊する場合の時間とひずみとの関係は， 三軸クリープ試験結果によれば, 図ー3(a), (b)に示すよう になり, 軸ひずみ速度が漸減する第一次クリープ領域, 軸ひずみ速度が定常となる第二次クリープ領域, 軸ひず み速度が増加し破壊に至る第三次クリープ領域とに区分 される。

斉藤・上沢は, 定常クリープ速度と破壊余裕時間（土 質試験では載荷から破壊するまでの時間であり, 地すべ り現場ではキレツの発生から滑落までの時間）が近似的 に逆比例することを実験的に明らかにし，両者の関係か ら(1)式を提案している2)。

$$
\log _{10} t_{r}=2.33-0.916 \log _{10} \dot{\varepsilon} \pm 0.59
$$

ここで, $t_{r}$ : 破壊余裕時間 (分)

$$
\dot{\varepsilon}: \text { ひずみ速度 (/分)，である。 }
$$

また，(1)式は，第三次クリープ領域にも成立するもの として, 地すべり滑落余裕時間の予測法を提案してい

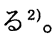




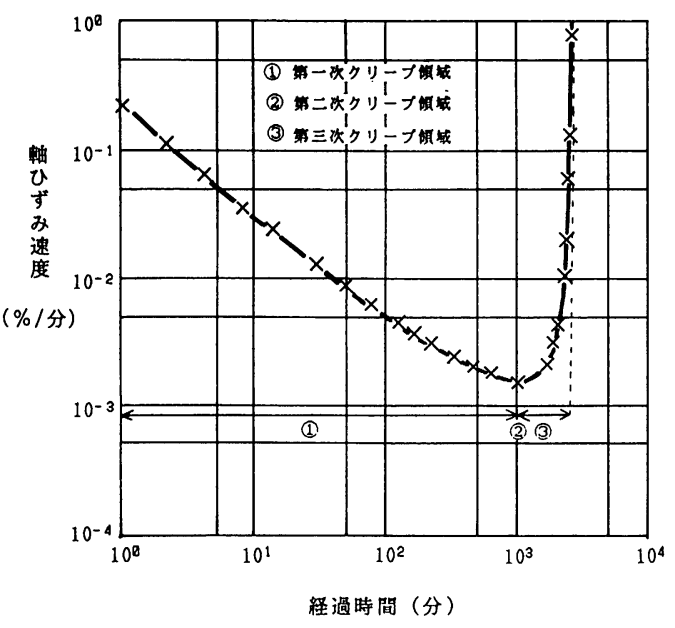

図ー3（a）軸ひずみ速度と経過時間との関係 ${ }^{16)}$

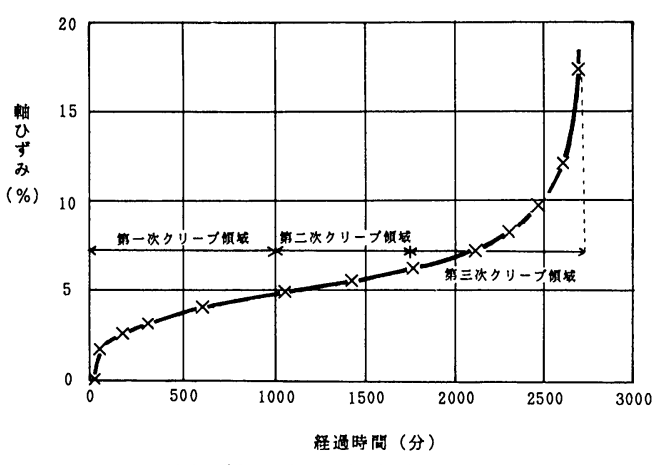

図ー3 (b) 軸ひずみと経過時間との関係 ${ }^{16)}$

(1)式では,ひずみ速度 (単位時間内の移動量 $\Delta l$ /移動量 測定区間長 $l)$ を用いており,移動量測定区間長は通常 10 $\mathrm{m}$ として取り扱われている場合が多い。しかし, 地すべ り移動量は, 一般に頭部クラックを挟んで測定されるも のであり, 地すべり地塊が一体となって移動している場

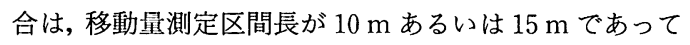
も同じである。したがって，移動量をひずみに変換する と, 同じ移動量であっても移動量測定区間長が異なった 場合には, 異なったひずみが得られ, 矛盾が生じること になる。このことから，管理基準值は，ひずみではなく 移動些をもとに設定することになる。ここでは, 用いた データが日単位であることから, 日移動量と地すべり滑 落余裕時間との関係について検討した。

地すべりの移動は, 図ー3(b)に示すようなクリープ曲 線を示すことは少なく, 図一 4 に示すようになる場合が 多い。このため, 図ー4に示すような地すべり移動に対し ても地すべり滑落余裕時間推定法が必要である。

移動速度から地すべり滑落余裕時間を推定する場合, 土がクリープ破壊するまでの軸ひずみが図ー3(a)に示す ようになることから, 同じ移動速度であっても, 属する
クリープ領域によって地すべり滑落余裕時間が異なるた め問題となる。しかし, 地すべりが滑落する際には, 必 ず第三次クリープ領域を経る。したがって, 地すべり滑 落余裕時間は, 第三次クリープ領域での移動速度との関 係を検討すれば求められると考える。ただし, 同じ移動 速度であっても, 属するクリープ領域によって地すべり 滑落余裕時間が異なるため, 第一次クリープ領域では余 裕時間が長くなり安全側となる。このことから, 余裕時 間を正確に求めるためには, 観測された移動量が, どの クリープ領域に属するかを移動速度の推移から判断する 必要がある。

図一 5,6 は, 図-1, 2 に示した各地すべりの移動観測 データをもとに日移動量と地すべり滑落余裕時間を求め, 両者の関係を示したものである。なお, 地すべり滑落余 裕時間は, 各地すべりの滑落時点から日移動量を求めた 時点間毎に算出した滑落までの余裕時間である。日移動 量と地すべり滑落余裕時間との関係は, 各地すべりとも 両対数グラフ上でほぼ直線関係にあり, 逆比例している ことが分かる。この結果は, 斉藤・上沢が明らかにした 第二次及び第三次クリープ領域におけるひずみ速度と破 壊余裕時間の関係と一致するものであり ${ }^{2)}$, 日移動量か

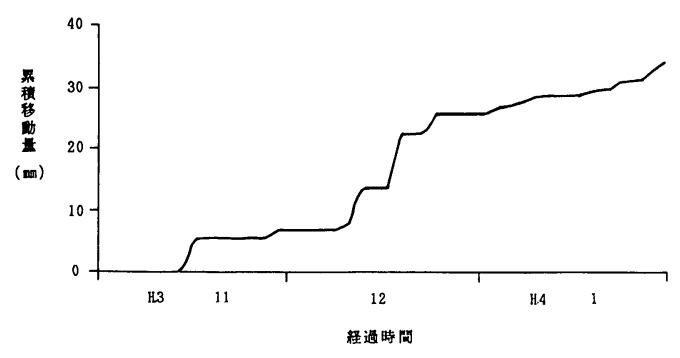

図ー4 沖見地すべり（新潟県）移動観測結果

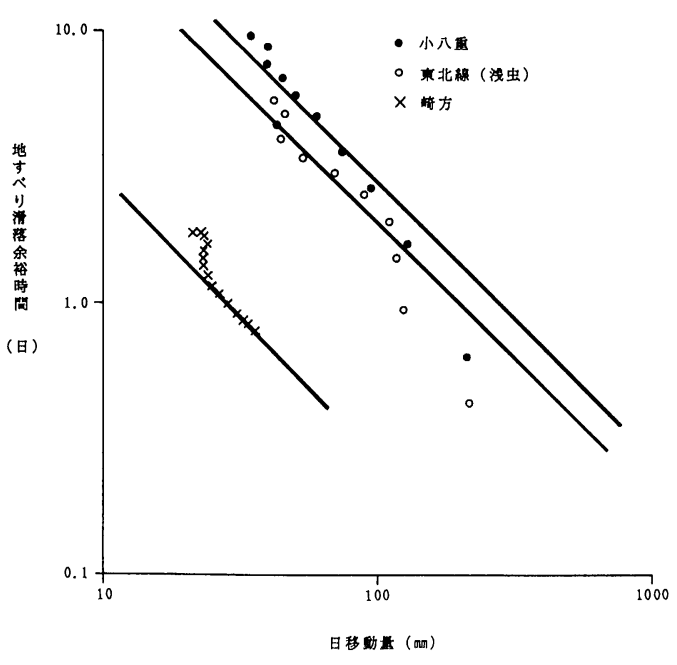

图ー5 日移動量と地すべり滑落余裕時間との関係(1) 
ら地すべり滑落余裕時間が求められ ると考える。

図-5, 6 には, 各地すべりの日移 動量と地すべり滑落余裕時間との関 係を示す勾配 1.0 の直線が記入して ある。なお，勾配 1.0 は(1)式をもと に決めた値である。各地すべりの日 移動量と地すべり滑落余裕時間との 関係は，切片が異なるものの，両対 数グラフ上において勾配が 1.0 の関 係式でほぼ表わされることが分かる。 しかし, 各地すべりの日移動量と地 すべり滑落余裕時間との関係を一つ にまとめ，地すべり滑落余裕時間の 予測式を作成したとしても，プロッ トされた点は,かなり大きな幅と なって図上に分布することになる。 ちなみに, 図一 5,6 に示すように JR 山陰本線（奈古～長門大井）と安居山, 柳谷, 小八重, 東北線（浅虫）とでは, 同じ日移動量であっても地すべ り滑落余裕時間は，1２桁も違っている。このことは， 現在, 管理基準値がほぼ一律な値で設定されているのに 対して，一律に設定するには無理があることを示すもの である。また，このままの両者の関係では, 日移動量か ら地すべり滑落余裕時間を精度良く求めることはできな い。しかし, 切片を地すべり地形を表わす数值等で求め ることができれば，予測式の精度を向上させることがで きると考える。

\section{3 地すべり地形を考慮した地すべり滑落余裕時間の} 予測

図－7には, 地すべり滑落前 1～5 日間の累積移動量と 斜面長（主体となって移動している地すべりブロックの 頭部から末端までの長さ）との関係を示した。図から， 地すべり滑落前 1〜5 日間の累積移動量が大きな地すべ りは, 斜面長が長いことが分かる。このことは, 斜面長 が長くなると地すべり滑落前の移動距離も大きくなるこ とを示すものであり, 図一6に示した安居山と JR 山陰 本線（奈古〜長門大井）での日移動量と地すべり滑落余 裕時間の関係と一致すると考える。そこで, 地すべり斜 面長と図 $-5,6$ に示したグラフの切片 $a$ との関係につい て検討した。

図一 8 には，地すべり斜面長と切片 $a$ との関係を両対 数グラフ上に示した。両者は, 直線関係にあることが分 かる。したがって, 図ー8に示した地すべり斜面長と図一 5，6（地すべり滑落余裕時間予測グラフ）に示したグラ フの切片との関係は，(2)式で表わされると考える。

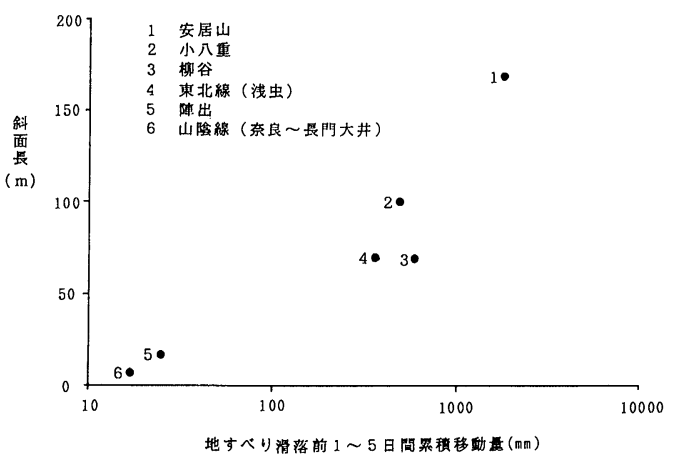

图ー7 地すべり滑落前 1〜 5 日間累積移動量と斜面長との関係

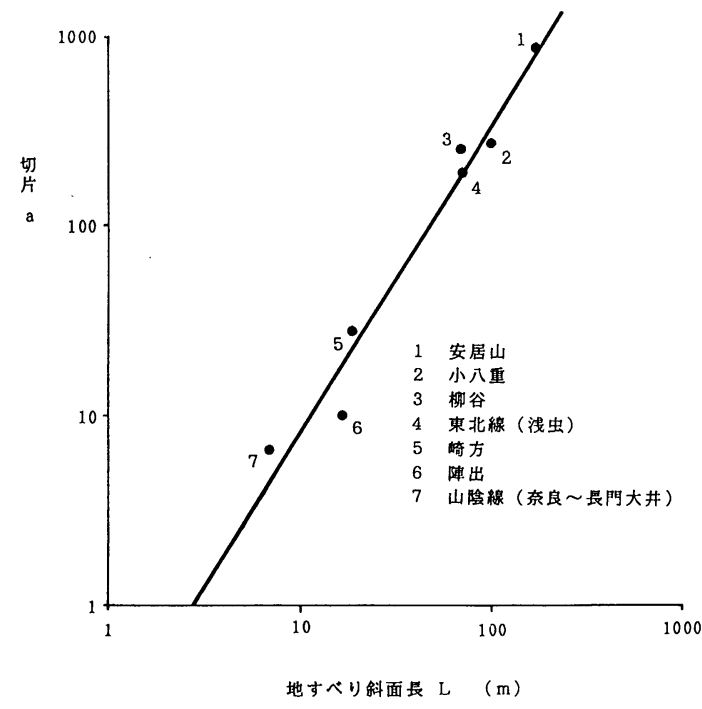

图ー8 地すべり斜面長と切片との関係 
地すべり Vol. 31 No. 1 (1994)

$a=0.204 L^{1.616}$

ここで, $a$ : 地すべり滑落余裕時間予測グラフの切片

$L:$ 地すべり斜面長（主体となって移動して いる地すべりブロックの頭部から末端ま での長さ：m), である。

以上のことから, 地すべり滑落余裕時間は，(3)式で表 わされると考える。

$\log _{10} T_{r}=\log _{10} a-\log _{10} \dot{D}$

ここで, $T_{r}$ : 地すべり滑落余裕時間（日）

$a:$ 地すべり滑落余裕時間予測グラフの切 片であり，(2)式で求められる。

$\dot{D}$ : 主体となって移動している地すべりブ ロック頭部の日移動量 ( $\mathrm{mm} /$ 日), であ る。

図ー9〜11には, (2), (3)式を用いて地すべり滑落余裕時 間を予測した結果を示した。予測した時間は, 安居山, 小八重については, 15〜20 日前の時点から実際の時間に ほほ近い値であり，概略的ではあるが，(2)，(3)式により 地すべり滑落余裕時間を予測できることが分かる。した がって, 地すべり滑落余裕時間を求める方法としては, 地すべり移動が第三次クリープ領域に入った初期の段階 あるいは，第三次クリープ領域でも十分に移動観測デー 夕が収集できていない段階では, 今回提案した方法によ り概略的な時間を予測する方法が，また，典型的な三次 クリープ曲線が得られた段階では, 斉藤・上沢の方法等 を用いて正確な時間を予測することが各々考えられる。 ただし, (2)式の地すべり斜面長 L は, 予測精度の良否に 影響することから，地すべり地の現地踏查及び動態観測 結果等をもとに慎重に求める必要がある。また，(2)式は デー夕数が不十分であることから，デー夕を蓄積し信頼 度を上げる必要がある。

\section{4 移動観測データによる管理基準値}

移動観測デー夕をもとに地すべり斜面の管理基準值を 設定することを目的として，管理基準値設定状況調査及 び移動観測データによる地すべり滑落余裕時間の予測法 の検討を行った。その結果, 管理基準值は, 地すべり地 関連, 道路関連, ダム関連では, 各々異なった值が設定 されているものの, 各関連毎にはほほ一律な值が設定さ れていることが分かった。しかし，地すべり地の移動観 測データをもとに地すべり滑落余裕時間の予測法につい て検討した結果では, 同じ日移動量であっても地すべり 毎に地すべり滑落余裕時間が異なっており，管理基準值 はこのことを考虑して設定することが考えられる。以下 に，地すべり地関連の管理基準值設定の考え方について 示した。

管理基準值は, 注意, 警戒, 避難, 立入禁止, の各段 階毎に設定する必要がある。注意段階では，管理基準值

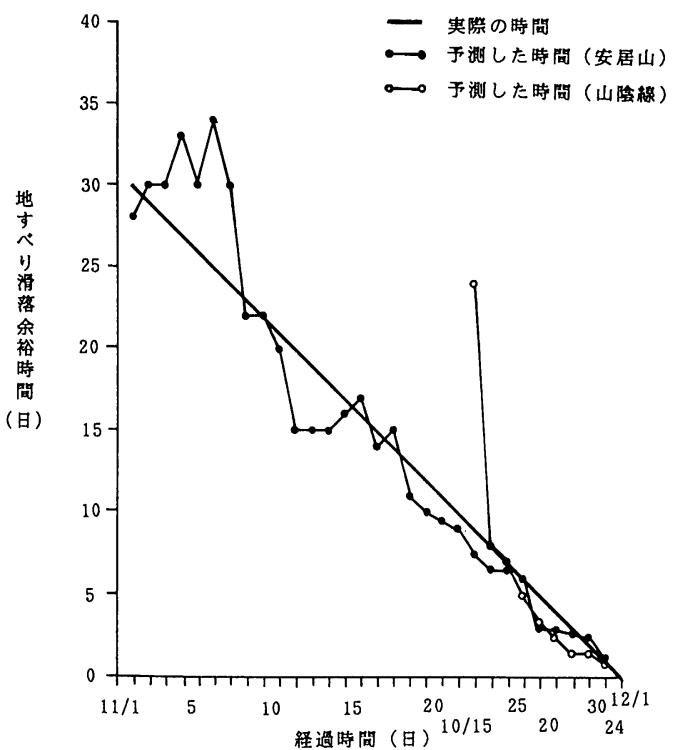

图ー9 地すべり滑落余裕時間の予測(1)
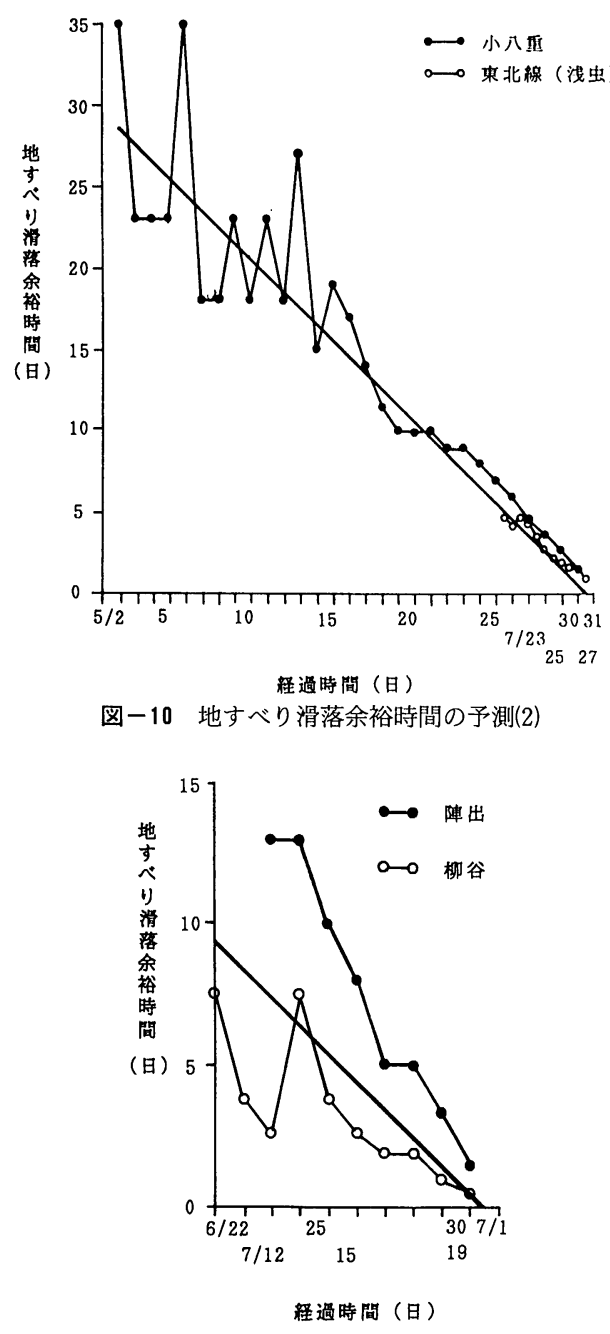

図ー11 地すべり滑落余裕時間の予測(3) 
として $1 \mathrm{~mm} /$ 日が多く設定されているが, 地すべりの動 きであるかどうかの認定を目的とするため, 伸縮計の精 度等を考慮すると，この值を一律に設定することは妥当 であると考える。また, 警戒〜立入禁止段階では, 管理 基準值を一律に設定したのでは, 地すべり滑落余裕時間 が地すべり毎に異なってくるため，被害を大きくするこ とも考えられる。したがって, 地すべり地毎に警戒〜立 入禁止の各段階に見合った地すべり滑落余裕時間を確保 した管理基準値を設定する必要がある。このための一つ の方法として，今回提案した方法を用いることが考えら れる。

\section{4.まとめ}

管理基準値の精度向上を図ることを目的として，管理 基準值の設定状況調査及び，移動観測データをもとにし た地すべり斜面の管理基準値の検討を実施した。その結 果は，以下に示す通りである。

（1）管理基準值の設定状況の調查では，次のことが分 かった。

(1) 地すべり地関連については, 注意及び警戒段階で は日移動量, 避難及び立入禁止段階では時間移動量 をもとに管理基準値が設定されている。また，管理 基準值は, 注意段階が $1 \mathrm{~mm} /$ 日, 警戒段階が 10 $\mathrm{mm} /$ 日，避難段階が $2 \mathrm{~mm} /$ 時が 2 時間継続した時 または $4 \mathrm{~mm} /$ 時，立入禁止段階が $10 \mathrm{~mm} /$ 時が多く 各々設定値とされている。

(2) 道路関連については, 点検, 応急対策・調査, 対 策の実施段階では日移動量が, 通行止めについては 時間移動量をもとに各段階の管理基準值が設定され ている。また，管理基準值は，通行止めでは $2 \mathrm{~mm} /$ 時が多く設定値とされている。

(3) ダム関連の管理基準值は，観測強化及び巡視の各 段階では日移動量で $0.4 \mathrm{~mm} /$ 日が 3 日間継続した 時, 試験湛水の中止では観測デー夕及び巡視結果を もとに専門家と協議して決められている。

（2）移動観測デー夕をもとにした地すべり斜面の管理基 準值の検討を行った結果では，次のことが分かった。

(1) 地すべり地の移動観測デー夕をもとに日移動量と 地すべり滑落余裕時間の関係について検討した結果 では，同じ日移動量であっても地すべり毎に地すべ り滑落余裕時間が異なっており，管理基準值はこの ことを考慮して設定することが考えられる。

(2) 日移動量と地すべり滑落余裕時間との関係は，両 対数グラフ上で逆比例の直線関係にあり，地すべり 毎に切片が異なるものの，勾配が 1.0 の関係式でほ ほ表わされる。
(3) (2)における切片は，地すべり斜面長（主体となっ て移動している地すべりブロック頭部から末端部ま での長さ）から(2)式で求めることができると考える。

(4) 地すべり滑落余裕時間は，(2)，(3)式で求めること ができると考えられ，地すべり発生初期あるいは十 分に移動観測データが収集できていない段階で有効 であると考える。

(5) 地すべり地関連の管理基準值の設定の考え方とし ては，注意段階では，地すべりの動きであるかどう かの認定を目的とするため，管理基準値を一律に設 定することができると考える。しかし，警戒〜立入 禁止段階では，各段階に見合った地すべり滑落余裕 時間を確保した管理基準值を地すべり毎に設定する 必要があり，(2)，(3)式を用いた方法が有効であると 考える。

今後は, 更にデータの蓄積を行い, 今回提案した地す ベり滑落余裕時間予測法の精度を向上させたい。

\section{参考文献}

1 ) 財高速道路調査会: 地すべり危険地における動態観測施 工に関する研究 (その2) 報告書 (日本道路公団委託), 昭 和 62 年 2 月

2) 斉藤迪孝: 斜面崩壊発生予知に関する研究, 鉄道技術研 究報告, No. 626,1968 年 2 月

3 ) 五十嵐武, 近藤政司, 丸山清輝, 上原慎一郎: 地すべり斜 面崩壊予測装置について, 第 19 回地すべり学会研究発表 論文集, pp. $20 \sim 23$, 昭和 55 年 11 月

4 ）江口正紀, 近藤政司, 丸山清輝: 三軸クリープ試験による 崩壊予測の試み, 第 22 回地すべり学会研究発表論文集, pp. 190 191, 昭和 58 年 7 月

5 ) 福直輝旗: 表面移動速度の逆数を用いた降雨による斜面 崩壊発生時刻の予測法, 地すべり, Vol. 22, No. 2, pp. $8 \sim 13,1985$

6) 川村國夫, 浅丘 顕, 西本俊治: 地すべり予知のためのパ ソコン利用，土と基礎，Vol. 34，No. 7, pp. 49〜 54, 1986

7 ) 大村 寛, 土屋 智: すべり面拡大モデルによるクリー プ現象の解析, 地すべり, Vol. 25, No. 1, pp. 1〜 6, 1988

8 ) 林 拙郎: 移動計測による崩壊発生時期の予測, 地すべ り学会関西支部シンポジウム “地すべり・斜面崩壊の予 知予測” 論文集, pp. 1 30, 平成 3 年 6 月

9 ) 山田剛二, 小橋澄治, 草野国重: 高場山トンネルの地すべ りによる崩壊, 地すべり, Vol. 8, No. 1, pp. 11〜24, 1971

10）関 信雄: 国道 33 号線柳谷地区岩盤斜面崩壊に対処し て, 地質と調查, pp. $30 \sim 35,1980$ 年第 3 号

11）渡 正亮: 安居山（福井）の地すべり運動, 施工技術, 第 6 巻第 7 号, pp. 109 112, 1973

12）堀伸三郎, 成田 賢, 関 信雄: 一般国道 33 号柳谷地区 斜面崩壊の予測, 地質学論集, No. 28, pp. 259 272, 1986

13）にゅうす, 鉄道土木, Vol. 8, No. 9, pp. 62〜63, 1966

14）中・古生層分布地域での切土のり面調査の方針，宮崎県, 平成 2 年 9 月

15）山梨県下部町役場: 昭和 58 年度町単道路工事地質調査 委託報告書, 1984

16) Finn, W. D. L. \& Snead, D. : Creep and Creep Rupture of an Undisturbed Sensitive Clay, Proc. 8th Int. Conf. on Soil Mech. \& Found. Eng'g., Moscow, Vol. 1-1, pp. 135 142, 1973

（原稿受理日 平成 5 年 1 月 29 日） 
堆積層における新規地すべりの発生予知

「地すべり」Vol. 31, No. 1（通巻第 117 号）pp. 1〜9, 1994 年（平成 6 年）6月

玉田 文吾, 福田 順二

新規の堆積層地すべりは，素因と誘因とによって，地層の特定部に連続したせん断破壊面（地すべり面）が形 成されることによって発生するが, この過程が地すべり予知と密接な関係がある。素因としては, 地款変動によっ て特殊な地層中に形成された潜在すべり面の存在が主なものであるが，これは一般に単位長に対して $0.15 \sim 0.25$ の未破壊部分を含有しているため, 誘因が働く毎に未破壊部分のクリープ破壊が連鎖的に発生し，せん断面の連 続化が進行する。これによって先端部（受働域）の隆起と破壊，始端部（主働域）の龟裂と段差とが，地表面の 進行性変状として数年前から顕著になる。これらの変状について連続的な観測と測定ができれば,一時的な現象 の中断などはあるが，発生時間は別として，位置，規模についての予知は可能である。

\section{土の一面剪断試験により作られた剪断層の構造}

「地すべり」Vol. 31, No. 1 (通巻第 117 号) pp. 10 20, 1994 年（平成 6 年）6 月

\section{岸本良次郎}

一面剪断試験機により，種々の発達段階にある剪断層を作り，その構造を軟 X 線写真により観察した。

破壊段階やクリープの段階に達した剪断層には，剪断面が多数樹枝状に密集している。さらにこれら剪断面に はそれぞれ，多数の小規模の剪断面が種々の仕方で連鎖している。

熱水性脈状粘土化帯と地すべりとの密接な関係一北海道金華峠地すべりの例一

「地すべり」Vol. 31, No. 1 (通巻第 117 号）pp. 21 28, 1994 年（平成 6 年） 6 月

前田 寬之

金華峠地すべりは，旧期地すべり地形の下部ユニットが再活動したものであり，その新・旧期地すべりはそれ ぞれ “粘質土地すべり”と“崩積土・粘質土地すべり”に相当する。これらの地すべり粘土はおもに多量のモン モリロナイトからなり，その鉣物の大部分は基岩の流紋岩溶岩の節理に沿う熱水性脈状モンモリロナイトーカオ リナイト帯に由来すると考えられる。したがって，これらの地すべりは熱水変質帯の産状や性状と密接な関連を もつ事例でもある。

\section{成層斜面の安定解析手法と斜面崩壊への適用}

「地すべり」Vol. 31, No. 1 (通巻第 117 号) pp. 29 36, 1994 年（平成 6 年） 6 月 渡辺 康二, 小川 正二

同じ岩質で構成され，比較的梁くまで風化が進んでいる斜面について「成層斜面の安定解析法」を適用する手 法を検討し，実際の斜面崩壊に適用した結果について述べている

\section{豪雪地帯の地すべり地における融雪水量の変動特性}

「地すべり」Vol. 31, No. 1 (通巻第 117 号) pp. 37〜44, 1994 年（平成 6 年） 6 月

松浦 純生, 竹内 美次, 落合 博貴, 梁瀬 秀雄

地すべり発生の重要な誘因となる融雪水量の実態を把握するため, 豪雪地帯の地すべり地で積雪を中心とする 気像観測を実施してきた。その結果，(1)冬期間の降水量の分布特性と降水種，(2)積雪初期および融雪期における 積雪底面からの融雪水の流出特性, (3)平年および少雪年における融雪水量の変動特性などが明かとなった。

\section{移動観測による地すべり斜面の管理基準值}

「地すべり」Vol. 31，No. 1（通巻第 117 号）pp. 45〜51，1994 年（平成 6 年）6月

丸山 清輝, 小嶋 伸一

地すべりの管理基準值の精度向上を図ることを目的として，管理基準值の設定状況調査及び，移動観測データ をもとにした管理基準值の検討を実施した。その結果, 同じ日移動量であっても，地すべり毎に滑落余裕時間が 異なっており，地すべり毎に管理基準值を設定する必要があることが分かった。そして，その方法として，地す ベり地形を考虑した地すべり滑落余裕時間の予測法を提案した。

地すべり地のエコロジカルな土地利用に関する提言

「地すべり」Vol. 31, No. 1（通巻第 117 号）pp. 52～55, 1994 年（平成 6 年）6月

岡村 俊邦

\section{鹿児島 8 月 6 日災害における土砂災害調査報告}

「地すべり」Vol. 31，No. 1（通巻第 117 号）pp. 56 63, 1994 年（平成 6 年）6月 北原一平, 河村 和夫, 佐口 治

平成 5 年 8 月 6 日に鹿児島市を中心に発生した土砂災害について, 写真判読を中心に災害特性調査を実施し, 報告した。調查内容は, 降雨特性調査, 地形・地質特性調査, および写真判読による崩壊発生特性調査である。

今回の災害は長雨後の集中豪雨が原因であったが, 日雨量の確率規模は 20 年〜30 年である。崩壊の発生简所は 地形・地質によって, シラス台地面浅谷の谷壁の斜面崩壊，シラス台地周辺部の斜面崩壊および山地の斜面崩壊 に区分される。最も人的被害が大きかったのは山地に区分される竜ケ水急傾斜地である。シラス台地の土砂災害 がほとんど表層崩壊であるのに対し，山地部の災害の特徵は斜面崩壊と土石流が混在していることである。写真 判読によると，この地区に扔ける土石流に対し，治山・砂防施設の効果が明らかに発揮されているところが多く 確認される。しかし，地形的な制約からハード対策では限界があり，総合的なソフト対策の検討も必要であるも のと考えられる。 